\title{
Phylogeographic and molecular characterization of Pronghorn spiny lobster (Panulirus penicillatus Olivier, 1791) in the Southern Coast of Java and Lombok, Indonesia
}

\author{
IRWANI ${ }^{1}$, DIAH PERMATA WIJAYANTI, ANINDIA WIRA SATRIA ${ }^{2}$, AGUS SABDONO ${ }^{1, \bullet}$ \\ ${ }^{1}$ Department of Marine Science, Faculty of Fisheries and Marine Science, Universitas Diponegoro. Jl. Prof. Soedharto, Kampus Undip Tembalang, \\ Semarang 50275, Central Java, Indonesia. Tel./fax.: +62-24-7474698, •email: agus_sabdono@yahoo.com \\ ${ }^{2}$ Department of Oceanography, Faculty of Fisheries and Marine Science, Universitas Diponegoro. Jl. Prof. Soedharto, Kampus Undip Tembalang, \\ Semarang 50275, Central Java, Indonesia
}

Manuscript received: 5 September 2020. Revision accepted: 21 November 2020.

\begin{abstract}
Irwani, Wijayanti DP, Satria AW, Sabdono A. 2020. Phylogeographic and molecular characterization of Pronghorn spiny lobster (Panulirus penicillatus Olivier, 1791) in the Southern Coast of Java and Lombok, Indonesia. Biodiversitas 21: $5690-5696$. Panulirus penicillatus is one of the most important lobster species in Central Java. It is one of the most populous species in the southern part of Java and Lombok. However, uncontrolled catching causes a decrease in the population of P. penicillatus. Despite such human threats, information about the taxonomic status of this species is limited. Several previous reports on the taxonomy of this species have always been based on the morphological features that cause ambiguous identification. Therefore, this study aimed to establish the relationships of $P$. penicillatus in southern parts of Java and Lombok by using the molecular technique. Twelve samples were collected from four study areas of the southern coast of the southern part of Java and Lombok and identified using DNA barcoding technique. DNA barcoding technique was used for the first time to identify $P$. penicillatus in this region. This study demonstrated that all specimens belonged to $P$. penicillatus. However, one specimen (PPK-06) showed high intraspecies nucleotide divergence that formed a distinct subclade. Therefore, the specimen (PPK-06) could represent a cryptic species within P. penicillatus that needs to be studied further.
\end{abstract}

Keywords: Cluster analysis, DNA barcoding, Java, Lombok, Panulirus penicilatus, south coast

\section{INTRODUCTION}

The spiny lobster, a member of the Family Palinuridae is the main target species for commercial fishery that support the economy of various countries (Heyman and Granados-Dieseldorff 2012; Diedrich et al. 2020). Global production of the fishery was valued to reach 260.000 metric tons per year with a landed value of approximately US\$500 million (Penn et al. 2015). However, most traded lobsters are obtained from wild-catching due to inadequate contribution of aquaculture sector (Priyambodo et al. 2020 Jones et al 2019; Jones 2010; Carpenter et al. 2011). During the last two decades, the mean size of wild catch lobsters is decreasing, more likely because of the intense fishing activity and lack of regulatory management. Currently, only Panulirus homarus and P. ornatus are farmed in the sea cages at Lombok, Indonesia, and Vietnam (Jones 2012; Jones et al. 2019).

One of the most important species in commercial fishery is the pronghorn spiny lobster, Panulirus penicillatus which probably has the widest global distribution among all the species of spiny lobster. The species is known to distribute throughout the entire IndoPacific regions, eastern and western regions of the Pacific Ocean (Holthuis 1991; Abdullah et al. 2014; Vaitheeswaran 2018), and even is found in the East Pacific (Chow et al. 2011). The species is found on rocky substrates, at shallow water less than $4 \mathrm{~m}$ depth, in the outer part of reef slopes and water channels (Cockcroft et al. 2013). The life cycle of individual species of Panulirus involved a very long pelagic stage that can last from several months up to almost 18 months in some species. The phyllosoma was then metamorphosed into puerulus which migrate towards the coast and settle at the shallow waters (Ernawati et al. 2017; Prince et al. 2020). This long pelagic life may facilitate the wide geographic distribution of the spiny lobster (Chow et al. 2011).

The pronghorn spiny lobster is traded as lobster tails in the form of fresh or frozen products with the Philippines and Indonesia are among the main exporter countries (Petersen et al. 2014)). In Indonesia, lobsters were caught from various regions such as along the southern coast of Java (Setyanto et al. 2019); the eastern part of Indonesia (Permana et al. 2014); Aceh Jaya, Kalimantan, Seram, and Raja Ampat (Wahyudin 2018). Indonesia Central Bureau of Statistics (BPS 2019) data showed that in the first quarter of 2014-2019, the value of Indonesia's lobster commodity exports reached 7.09 million USD. The harvest rate of spiny lobsters in Indian Ocean among 11 WPP (Fisheries Management Area) has almost reached the total allowable catches (TAC) value (Wahyudin 2018).

The southern coast of Java is one of the main sources of spiny lobster production. The region contributes up to $10 \%$ of the national catch. The fishery in southern Java is 
operated using two different gears, namely a tangled trap and an inshore bottom gillnet (Milton et al. 2014). There are 6 main targeted species of the fishery with $P$. homarus and $P$. penicillatus are the major catches. Despite being one of the main sources of the spiny lobster production, there is no report on the population distribution of $P$. penicillatus in Southern Java. A study on the exploitation rate of the species based on biological factors and the mortality rates suggested that the species is under overexploitation (Larasati et al. 2018). Therefore, it is necessary to investigate the genetic relationship among the pronghorn spiny lobster populations in Southern Java to obtain data on the sustainability of the species as well as to provide information on larvae sources through the current model which transport the larvae through the region. Oceanographic current presumably involves in producing the geographic barrier and directions of larval dispersal (Johannesson et al. 2019; White et al. 2010; SanvicenteAñorve et al. 2018). In this study, we analyzed the highly polymorphic marker, mitochondrial DNA (mtDNA) control region of $P$. penicillatus to determine whether genetic diversity could be detected in Southern Java and Lombok populations and the relationship among populations by modeling the current.

\section{MATERIALS AND METHODS}

\section{Lobster sampling}

Sampling was done by getting the catches of fishermen who have fishing activities on the southern coast of Java and Lombok. After landing in the port, the result of lobster's catch from the fishermen was sampled randomly. A total of 12 individuals of $P$. penicillatus were examined morphologically, then placed in the ice-cool box and brought directly to Marine Science Laboratory for further analyses. Sampling site was shown in Figure 1.

\section{Molecular technique}

Total genomic DNA was extracted from each sample using a modified Gopal protocol (Gopal et al. 2006). Muscle tissue samples for mitochondrial extraction (mtDNA) were taken from the leg of the first pleopod with a size of $0.2 \mathrm{~mm}$. Then the muscle was ground using a mortar and pestle, placed in a $1.5 \mathrm{ml}$ mini tube that contains a $100 \mu \mathrm{L}$ Aliquot $20 \%$ chelex (DNA extractor) and closed, then vortex for 10-15 seconds. To separate the supernatant, the sample was centrifuged at a speed of $10,000 \mathrm{rpm}$ for 1 minute. Furthermore, the samples were incubated at $95{ }^{\circ} \mathrm{C}$ for 20 minutes, vortexed again for $10-15$ seconds, and re-centrifuged for 10-15 minutes at 10,000 rpm. The resulting supernatants containing the genomic DNA were transferred to a new tube.

Supernatant produced from DNA extraction in the microtube was then added with $2 \mu \mathrm{L}$ universal primer (R) (LCO-ph): 5'- GGTCAACAAATCATAAAGATATTGG3' and Primer Forward (F) (HCO-ph): 5'TAAACTTCAGGGTGACCAAAAAATCA -3', $6 \mu \mathrm{L}$ dd $\mathrm{H} 2 \mathrm{O}, 2,5 \mu \mathrm{L}$ DNA template and $12.5 \mu \mathrm{L}$ Green Master Mix, in total $25 \mu \mathrm{L}$ PCR mix solution. PCR products were purified using the Qiagen gel cleanup system, separated by using electrophoresis, and visualized by using a UV transilluminator, and the good quality PCR products were selected and sent to PT. Indolab, Jakarta, Indonesia for nucleotide sequencing.

\section{Construction of phylogenetic-tree}

Phylogenetic-tree was constructed according to the method of Sabdono et al. (2019). The CLUSTAL X and the PAUP*4.0 software package were used to establish the tree. The DNA sequences were submitted to the GenBank database with accession numbers from MT750271 to MT750282. The COI sequences of Acanthacaris tenuimana KF828006.1 was used as an Outgroup.

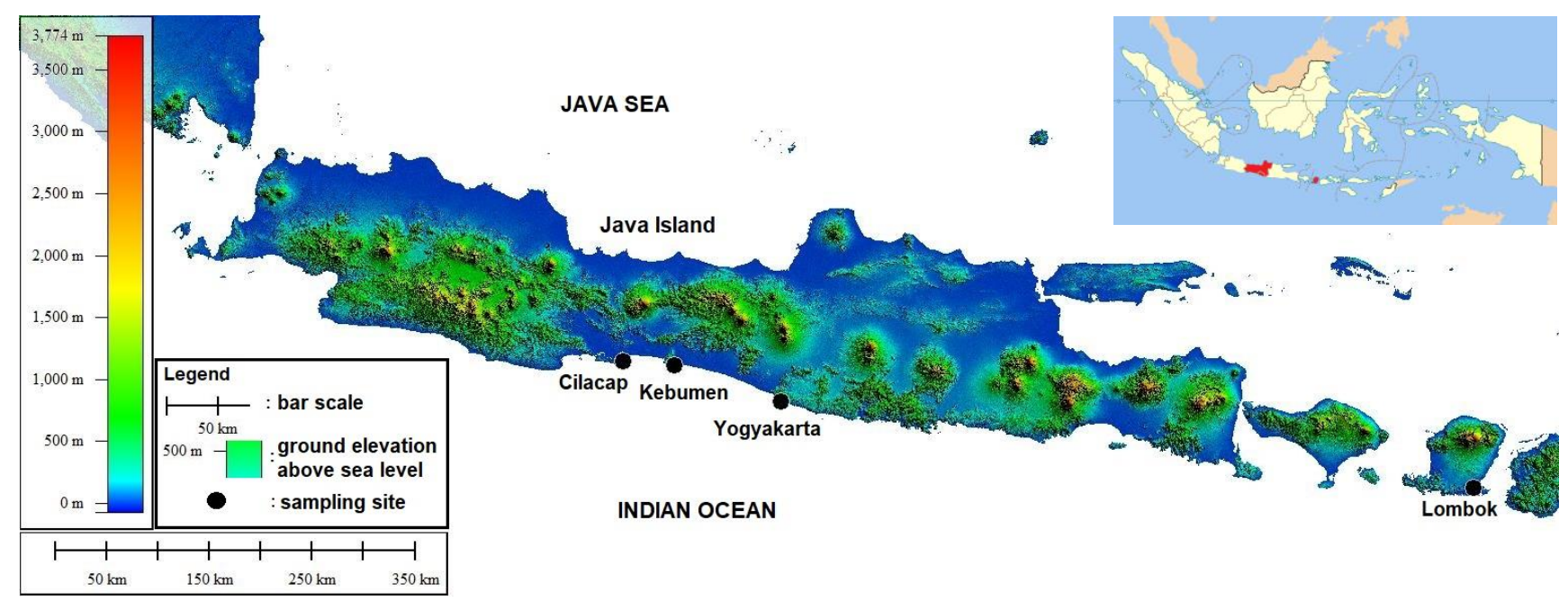

Figure 1. Sampling site locations of Panulirus penicillatus on south coast of Java and Lombok islands, Indonesia 


\section{Dataset}

We used surface current data to investigate the possible mechanisms of the genetic distribution of $P$. penicillatus. Surface current data was obtained from the monthly Global Reanalysis Ensemble Product from Mercator Ocean at 1/4 resolution (Gounou et al. 2020) from December 2017 to November 2018. This dataset was produced by combining numerical ocean models constrained with data assimilation of satellite and in situ observations (i.e., GLORYS2V4 from Mercator Ocean (France), ORAS5 from ECMWF, GloSea5 from Met Office (UK) and C-GLORS05 from CMCC (Italia)). The multi-model ensemble approach provides a more reliable dataset than the individual reanalysis product since the estimation of the uncertainties or error bars in the ocean state can be estimated. This dataset can be downloaded at https://resources.marine.copernicus.eu/?option=com_csw\& view=details\&product_id=GLOBAL_REANALYSIS_PH Y_001_031. The analysis was conducted based on season i.e., southeast monsoon and northwest monsoon season. We calculated June, July, and August (December, January, and February) data to construct a southeast (northwest) monsoon mean map.

\section{RESULTS AND DISCUSSION}

\section{Morphological characteristics within the lobster of Panulirus penicillatus}

A total of 12 individual species of $P$. penicillatus were used in this research. Samples were collected from four study areas of the south coast of Java and Lombok namely Cilacap, Kebumen, Gunung Kidul, and Lombok. Lobster's samples of $P$. penicillatus from the four locations showed a slight morphological difference in colors (Figure 2). The lobster's body colors ranged from yellowish blue-green to reddish through dark brown depending on their habitat origins. Holthuis (1991) reported the detailed diagnosis of the lobster P. penicillatus based on their body color (from yellowish-green to blue-black) depending on habitat and morphometry (spines on the antennular plate grooves on the abdomen and exopod of the flagellum).
Table 1. Details of Panulirus penicillatus samples from 4 different locations

\begin{tabular}{cllcc}
\hline $\begin{array}{c}\text { Sample } \\
\text { code }\end{array}$ & $\begin{array}{c}\text { Sampling } \\
\text { location }\end{array}$ & Sex & $\begin{array}{c}\text { Carapace } \\
\text { length }(\mathbf{c m})\end{array}$ & $\begin{array}{c}\text { Weight } \\
(\mathbf{g})\end{array}$ \\
\hline PPC-04 & Cilacap & Female & 6.45 & 186 \\
PPC-06 & Cilacap & Male & 5.50 & 134 \\
PPG-05 & Gunungkidul & Male & 4.82 & 90 \\
PPG-06 & Gunungkidul & Female & 4.98 & 103 \\
PPG-07 & Gunungkidul & Male & 4.50 & 74 \\
PPK-06 & Kebumen & Female & 5.48 & 141 \\
PPK-07 & Kebumen & Male & 5.39 & 133 \\
PPK-08 & Kebumen & Male & 5.09 & 114 \\
PPL-06 & Lombok & Female & 6.17 & 216 \\
PPL-07 & Lombok & Female & 6.89 & 279 \\
PPL-08 & Lombok & Female & 6.65 & 255 \\
PPL-09 & Lombok & Female & 6.60 & 236 \\
\hline
\end{tabular}

Table 1 showed that carapace length of the lobsters varied between 4.50 and $6.89 \mathrm{~cm}$, while the carapace weight was between 74 and $279 \mathrm{~g}$, respectively. The sex determination demonstrated that samples contain more female than male lobster. Previous studies reported that the weight and length intervals of carapace spiny lobsters of Bantul and Cilacap were varied between 6.5 and $771.7 \mathrm{~g}$, and 2.7 to $10.3 \mathrm{~cm}$ (Haryono et al. 2016). While, Ongkers et al. (2014) reported that the interval weight of carapace spiny lobsters of Latulahat, Ambon ranged from 101 to $1130 \mathrm{~g}$, and the carapace length ranged from 6.0 to 14.1 $\mathrm{cm}$.

\section{Molecular identification of Panulirus penicillatus}

The sequences of $P$. penicillatus COI region were analyzed homologically by using BLAST (Altschul et al. 1990). The result showed that the sequences of specimens collected in this study were similar to the deposited sequences on GenBank and recorded as $P$. penicillatus (Acc no. MT750271to MT750282).

Even there were slight differences in body's colors of lobster's samples (Figure 2), however, DNA sequenced analyses showed that the specimens used in this study indeed all belonged to $P$. penicillatus (Table 2).

Table 2. Homology analyses of Panulirus penicillatus from 4 different locations

\begin{tabular}{|c|c|c|c|c|c|}
\hline Sample code & BLAST Identification & Voucher & Base Pair & Per ident. & Accession number \\
\hline PPC-04 & Panulirus penicillatus & Cilacap & 674 & $99.54 \%$ & MT750271 \\
\hline PPC-06 & Panulirus penicillatus & Cilacap & 674 & $99.85 \%$ & MT750272 \\
\hline PPG-05 & Panulirus penicillatus & Gunungkidul & 674 & $99.85 \%$ & MT750273 \\
\hline PPG-06 & Panulirus penicillatus & Gunungkidul & 674 & $100 \%$ & MT750274 \\
\hline PPG-07 & Panulirus penicillatus & Gunungkidul & 674 & $99.55 \%$ & MT750275 \\
\hline PPK-06 & Panulirus penicillatus & Kebumen & 640 & $98.75 \%$ & MT750276 \\
\hline PPK-07 & Panulirus penicillatus & Kebumen & 674 & $100 \%$ & MT750277 \\
\hline PPK-08 & Panulirus penicillatus & Kebumen & 674 & $99.85 \%$ & MT750278 \\
\hline PPL-06 & Panulirus penicillatus & Lombok & 674 & $99.84 \%$ & MT750279 \\
\hline PPL-07 & Panulirus penicillatus & Lombok & 674 & $99.85 \%$ & MT750280 \\
\hline PPL-08 & Panulirus penicillatus & Lombok & 674 & $99.70 \%$ & MT750281 \\
\hline PPL-09 & Panulirus penicillatus & Lombok & 674 & $99.85 \%$ & MT750282 \\
\hline
\end{tabular}



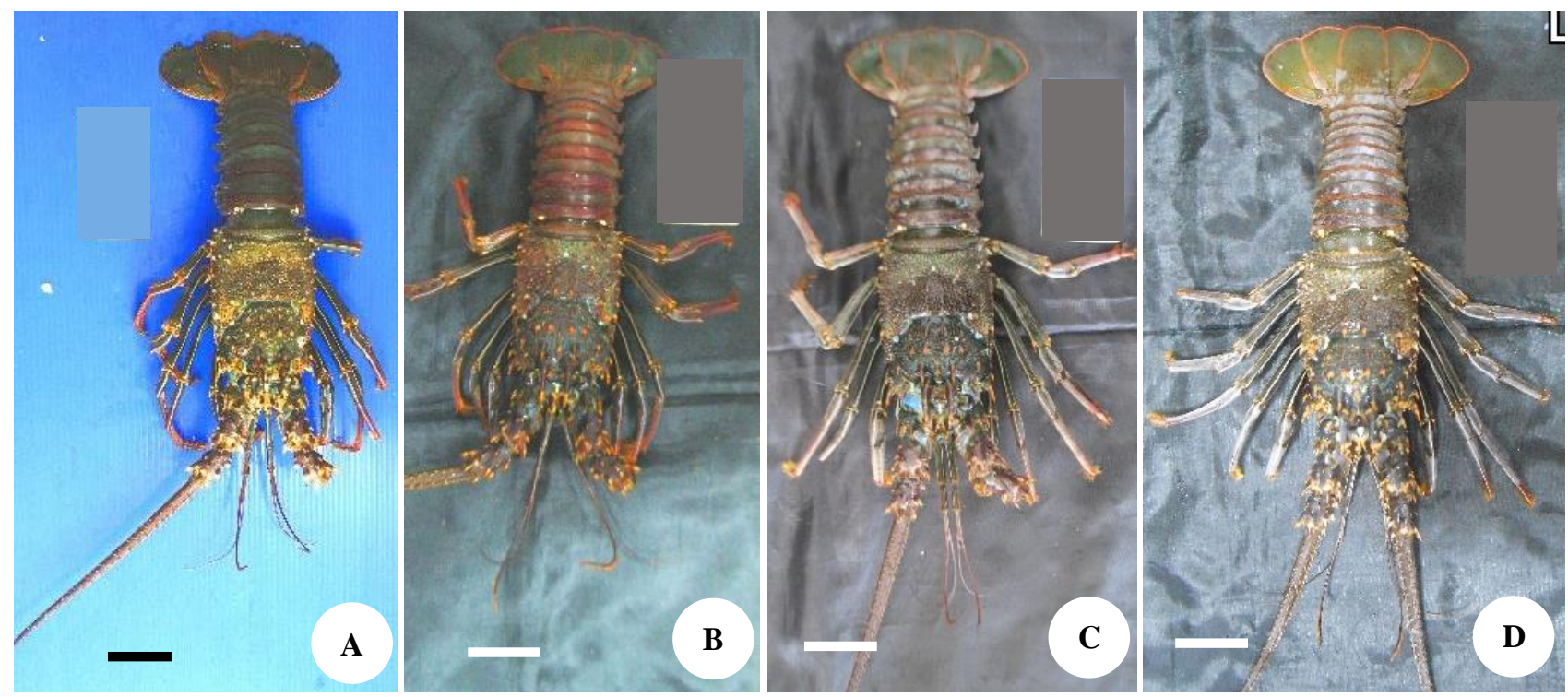

Figure 2. Morphological convergence of Panulirus penicillatus from different site collections. Note: A. Lombok; B. Gunung Kidul; C. Kebumen; D. Cilacap. (Photograph by Irwani). Bar $=3 \mathrm{~cm}$

\section{Discussion}

Color variation in crustaceans is a complex subject because of the variety of mechanisms that might cause the changes (Stevens et al 2007). Lobsters come in many different colors because of the pigment chromatophores in their shells. Lobsters come in many different colors because of the pigment chromatophores in their shells. Color variation is one of the many spatial differences in the biology of Lobster. Colour plays an important role in grading and marketing the Lobster (Bryars \& Geddes 2005). In Southern rock lobster, Jasus edwardsii, the red color of the lobster was influenced by the depth where the lobsters were fished. The number of red colors will decrease with depth while the paler lobster mostly is dominated by the deeper depth (Chandrapavan et al. 2009). Although lobster color is also controlled genetically, the mechanism by which phenotypic color is controlled has not yet been revealed (Tlusty et al. 2009; Duarte et al. 2017). Some previous studies reported that the coloration of many crustacean tissues was controlled by the type and amount of carotenoids ingested and a number of environmental factors, such as the color of the background substrate, light intensity, photoperiod, and temperature, which may also produce physiological color changes in crustaceans (Wade et al 2005; Tlusty et al. 2009).

NJ clustering analysis showed that there were different clades among the sequences of $P$. penicillatus in the southern parts of Java and Lombok, India, Australia, and the Philippines (Figure 3). It seems that there were no apparent geographical barriers among the sampled regions. This is likely related to its life cycle and the high dispersal capacity of its planktonic larvae. Previous studies on the free-floating phyllosoma larval phase (Matsuda et al. 2006) reported that spawning and early larval stages of $P$. penicillatus in oceanic waters probably exceeded 8-11 months. These early larval stages exhibit high dispersal capacity, often more related to ocean currents and winds.

Figure 4 shows the distribution of surface current patterns on the southern coast of Java. Alternating current direction is obtained on the southern coast of Java known as the South Java Coastal Current (SJCC). SJCC is the main current system on the southern coast of Java generated by the local wind forcing and the wind-forced equatorial Kelvin waves (Utari et al. 2019). During the northwest monsoon season, the SJCC moves eastward while during the southeast monsoon season, the westward current dominates in this region. The magnitude of westward SJCC is greater than eastward SJCC due to the influence of Indian Throughflow (ITF) which flows in the same direction as the westward SJCC. As reported by Sprintall et al. (2010) SJCC is regulated by ITF that exits from the Lombok Strait. Furthermore, the weak southward current is observed along the onshore area during the southeast monsoon season. This weak southward current corresponds to the occurrence of coastal upwelling which has been reported by many researchers (e.g. Iskandar et al. 2009; Wirasatriya et al. 2020). Cyclonic eddy is also detected at the eastern part of the southern coast of Java. This indicates an upwelling occurrence induced by negative Ekman pumping as has been demonstrated by Wirasatriya et al. (2020). The alternating current pattern along the southern coast of Java, Bali, and Lombok may cause the genetic similarity of the lobsters distributed in those areas. However, some questionable points are still obtained from the phylogenetic tree as shown in Figure 3. The lobsters in southern Java and Lombok have different subclades from the lobsters in India, Australia, and the Philippines. The present study revealed that there is no ongoing gene flow between the southern coast of Java and Lombok and Indian, Australian, and the Phillippines $P$. penicillatus populations. In contrast, very little evidence of 
population structuring was observed within southern coast of Java and Lombok. It is unusual that PPK-06 species found in Kebumen waters showed different sub-subclades from the other species of southern coast Java and Lombok in the studied population. In general, it could be said that the presence of lobsters on the southern coast of Java and Lombok is supported by the entry of lobsters from eastern Indonesia, local spawning lobsters, and possible input of lobsters from western Indonesia. Despite the long pelagic larval period common to all spiny lobster species, a narrow distribution range is observed in several species of Panulirus. Chow et al. (2011) stated that spiny lobster species having very wide geographic distributions may show regional variation in population structure. The result should be investigated further in more detail using larger sample sizes and more variable genetic markers. Further current pattern analysis for the wider region should also be conducted to examine this problem.

Our findings suggest that $P$. penicillatus consist of a monophyletic clade within its known distribution range on southern coast of Java and Lombok, and challenge current models for the predicted dispersal of the- species. Additional sampling of $P$. penicillatus populations in this area are required to fully understand the diversity of this group.

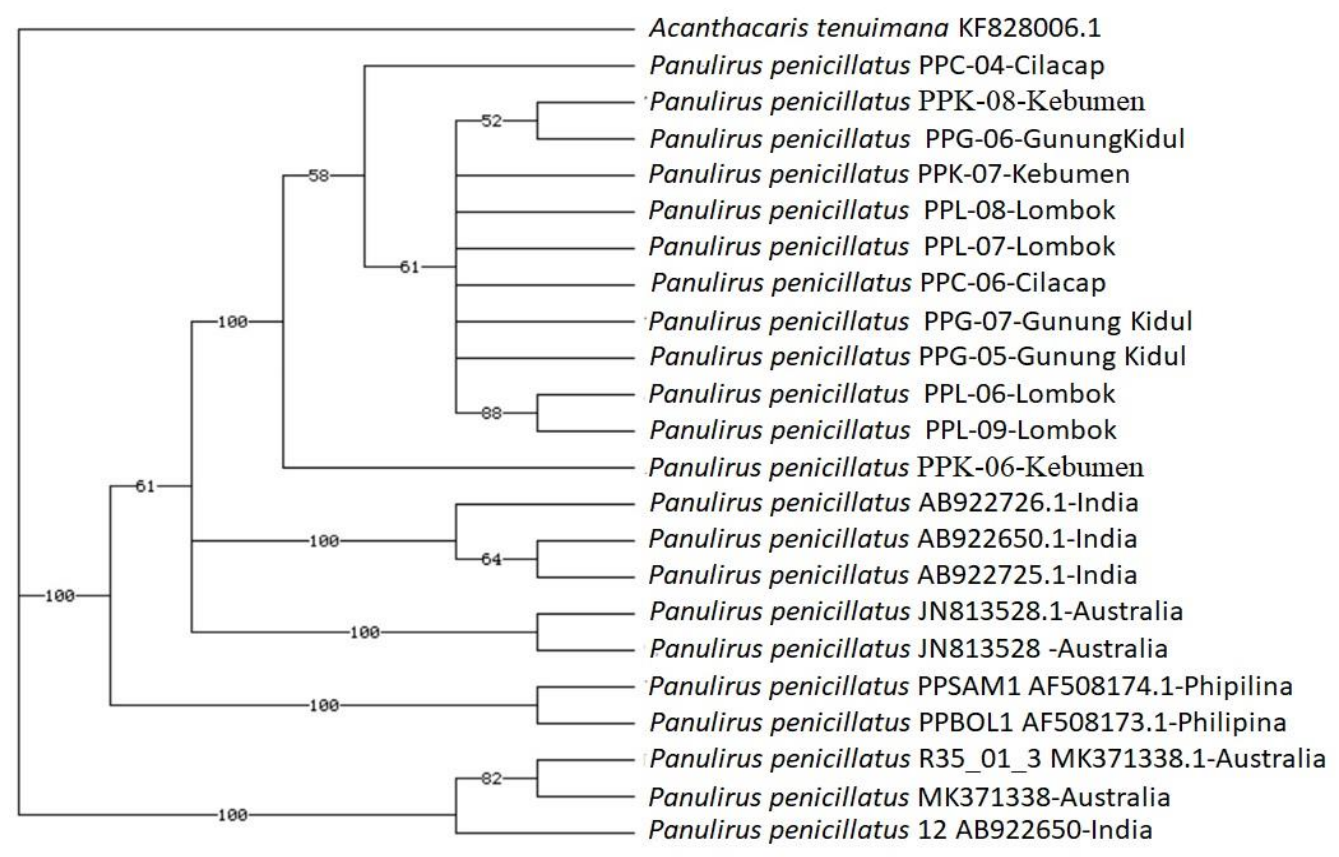

Figure 3. Phylogenetic tree based on comparative COI mtRNA gene sequence analysis of Panulirus penicillatus species showing the phylogenetic affiliation of the southern coast of Java and Lombok, Indonesia. Acanthacaris tenuimana KF828006.1 was used as an outgroup.

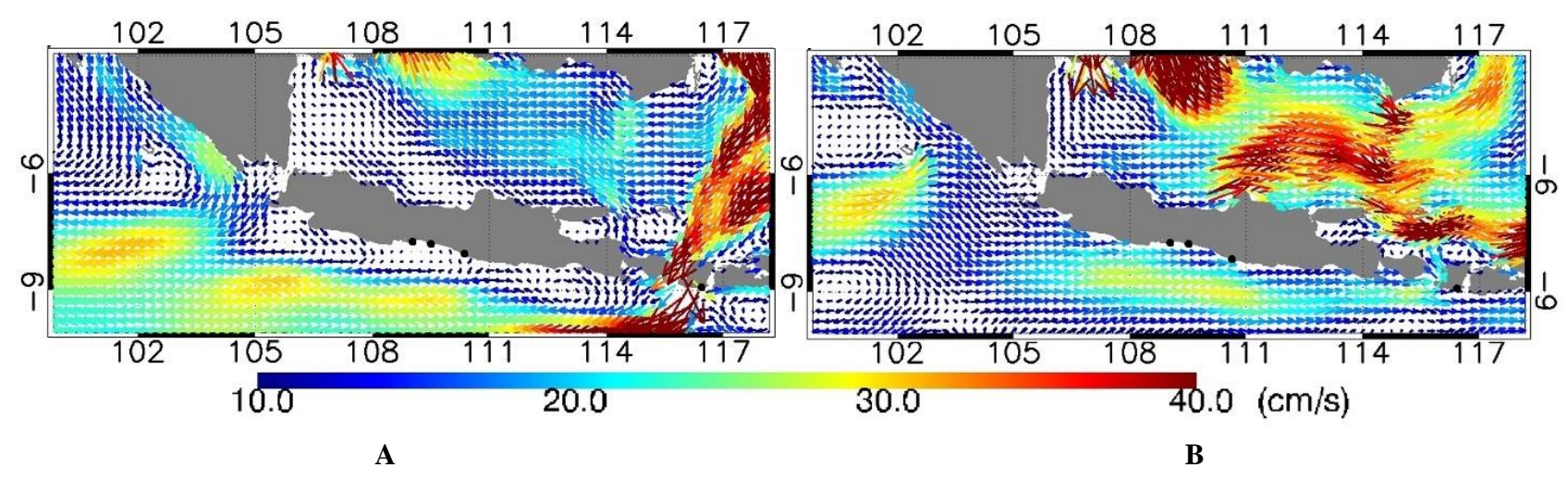

Figure 4. Map of the mean surface current pattern along the southern coast of Java during a) Southeast monsoon season (June, July, August) and b) Northwest monsoon season (December, January, February) 


\section{ACKNOWLEDGEMENTS}

This work was supported by a dissertation grant from Diponegoro University, Semarang, Indonesia. The authors are grateful to Sakti and Abi for helping in laboratory work.

\section{REFERENCES}

Abdullah MF, Alimuddin, Muththalib M, Salama AJ, Imai H. 2014 Genetic Isolation among the Northwestern, Southwestern and CentralEastern Indian Ocean Populations of the Pronghorn spiny lobster Panulirus penicillatus. Intl J Mol Sci 15 (6): 9242-9254.

Atschul SF, Madden TL, Schaffer AA, Zhang J, Zhang Z, Miller W, Lipman DJ. 1997. Gapped BLAST and PSI-BLAST: A new generation of protein database search programs. Nucleic Acids Res 25: 3389-3402.

Bryars SR, Geddes MC. 2005. Effects of diet on the growth, survival, and condition of sea-caged adult Southern Rock Lobster, Jasus edwardsii. N Z J Mar Freshw Res 39: 251-262.

BPS. 2019. Badan Pusat Statistik. Perikanan. https://www.bps.go.id/subject/56/perikanan.html\#subjekViewTab3. [Indonesian]

Carpenter KE, Barber PH, Crandall ED, AblanLagman MCA Ambariyanto, Mahardika GN, Manjaji-Matsumoto BM, Juinio-Meñez MA, Santos MD, Starger CJ, Toha AHA. 2011. Comparative phylogeography of the coral triangle and implications for marine management. J Mar Biol. DOI: 10.1155/ 2011/396982.

Chandrapavan A, Gardner C, Linnane A, Hobday D. 2009. Colour variation in the southern rock lobster Jasus edwardsii and its economic impact on the commercial industry. N Z Mar Freshw Res 43: 537-545.

Chow S, Jeffs A, Miyake Y, Konishi K, Okazaki M, Suzuki N, Abdullah MF, Imai H, Wakabayasi T, Sakai M. 2011. Genetic isolation between the Western and Eastern Pacific populations of Pronghorn spiny lobster Panulirus penicillatus. PLoS ONE 6 (12): e29280. DOI: 10.1371/journal.pone.0029280.

Cockcroft A, MacDiarmid A, Butler M. 2013. Panulirus penicillatus. The IUCN Red List of Threatened Species 2011: e.T169951A6691002. DOI: 10.2305/IUCN.UK.2011-1.RLTS.T169951A6691002.e.

Ernawati T, Sumioino B, Madduppa H. 2017. Reproductive ecology, spawning potential, and breeding season of blue swimming crab (Portunidae: Portunus pelagicus) in Java Sea, Indonesia. Biodiversitas 18: 1705-1713. DOI: 10.13057/biodiv/d180451.

Gopal K, Tolley KA, Groeneveld JC, Matthee CA. 2005. Mitochondrial DNA variation in spiny lobster Palinurus delagoae suggests genetically structured populations in the southwest Indian Ocean. Mar Ecol Prog Ser 319: 191-198. DOI: 10.3354/meps319191.

Gounou A, Drévillon M, Clavier M. 2020. Product user manual for Global Ocean Reanalysis Products global-reanalysis-phy-001-031. Marine.copernicus.eu.

Haryono FED, Hutabarat S, Hutabarat J, Ambariyanto. 2016. Comparation of spiny lobster (Panulirus sp.) populations from Bantul and Cilacap, Central Java, Indonesia. J Teknologi 78: 51-54.

Heyman WD, Granados-Dieseldorff P. 2012. The voice of the fishermen of the Gulf of Honduras: improving regional fisheries management through fisher participation. Fish Res 125/126: 129-148.

Holthuis LB. 1991. Marine Lobsters of the World: an annotated and illustrated catalogue of species of interest to fisheries known to date. FAO Species Catalogue No. 13. FAO, Rome.

Iskandar I, Rao SA, Tozuka T. 2009. Chlorophyll-a bloom along the southern coasts of Java and Sumatra during 2006. Intl J Rem Sens 30 (3): 663 - 671. DOI: 10.1080/01431160802372309.

Johannesson K, Ring AK, Johannesson KB, Renborg E, Jonsson PR, Havenhand JN. 2018. Oceanographic barriers to gene flow promote genetic subdivision of the tunicate Ciona intestinalis in a North Sea archipelago. Mar Biol 165: 126. DOI: 10.1007/s00227-018-3388-x.

Jones CM, Anh TL, Priyambodo B. 2019. Chapter 12. Lobster aquaculture development in Vietnam and Indonesia. In: Radhakrishnan EV, Phillips BF, Achamveetil G (eds.). 2019. Lobsters: Biology, Fisheries and Aquaculture. Springer Nature, Singapore. DOI: 10.1007/978-981-32-9094-5_1.
Jones CM. 2010. Tropical rock lobster aquaculture development in Vietnam, Indonesia and Australia. J Mar Biol Assoc India 52: 304-315.

Jones C. 2012. Cultured aquatic species information programme. Panulirus homarus. FAO Fisheries and Aquaculture Department, Rome.

Lavery SD, Farhadi A, Farahmand H, Chan TY, Azhdehakoshpour A Thakur V, Jeffs AG. 2014. Evolution divergence of geographic subspecies within the Scalloped spiny lobster Panulirus homarus (Linnaeus 1758). PLoS ONE 9 (6): e97247. DOI: 10.1371/journal.pone.0097247.

MacArthur L, Hyndes G, Babcock R. 2007. Western rock lobster in ecosystem processes of south-western Australia. Report No 12-2007. Department of Environment, Water, Heritage and the Arts, Canberra, Australia.

Larasati RF, Suadi, Setyobudi E. 2018. Short Communication: Population dynamics of double-spined rock lobster (Panulirus penicillatus Olivier, 1791) in Southern Coast of Yogyakarta. Biodiversitas 19: 337-342.

Matsuda H, Takenouchi T, Goldstein JS. 2006. The complete larval development of the Pronghorn spiny lobster Panulirus penicillatus (Decapoda, Palinuridae) in culture. J Crustacean Biol 26: 579-600.

Milton DA, Satria F, Proctor CH, Prasetyo AP, Utama AA, Fauzi M. 2014. Environmental factors influencing the recruitment and catch of tropical Panulirus lobsters in southern Java, Indonesia. Continental Shelf Res 91: 247-255.

Moss J, Behringer DC, Shields JD, Baeza A, Aguilar-Perera A, Bush PG, Dromer C, Herrera-Moreno A, Gittens L, Matthews TR, McCord MR, Schärer MT, Reynal L, Truelove N, Butler MJ IV. 2013. Distribution, prevalence, and genetic analysis of Panulirus argus virus 1 (PaV1) from the Caribbean Sea. Dis Aquat Organ 104: 129-140.

Ongkers OT, Pattiasina BJ, Tetelepta JMS, Natan Y, Pattikawa JA. Some biological aspects of painted spiny lobster (Panulirus versicolor) in Latuhalat waters, Ambon Island, Indonesia. AACL Bioflux 7 (6): 469-474.

Penn JW, Caputi N, de Lestang S. 2015. A review of lobster fishery management: the Western Australian fishery for Panulirus cygnus, a case study in the development and implementation of input and output-based management systems. ICES J Mar Sci 72:22-34. DOI:10.1093/icesjms/fsv057.

Permana GN, Slamet B, Permana BA, Dewi AY, Mahardika GN. 2019. Population genetic structure of spiny lobsters, Panulirus homarus and Panulirus ornatus, in the Indian Ocean, Coral Triangle, and South China Sea. Hindia Aquaculture J 14 (1): 7-14.

Petersen EH, Jones C, Priyambodo B. 2014. Bioeconomics of spiny lobster farming in Indonesia. Asian J Agric Dev 10 (1): 25 - 39.

Phillips BF, Brown PA, Rimmer DW, Reid DD. 1979. Distribution and dispersal of the phyllosoma larvae of the Western rock lobster, Panulirus-cygnus, in the Southeastern Indian-Ocean. Austr J Mar Freshw Res 30: 773-778.

Priyambodo B, Jones CM, Sammut J. 2020. Assessment of the Lobster Puerulus (Panulirus homarus and Panulirus ornatus, Decapoda: Palinuridae) resource of Indonesia and its potential for sustainable harvest aquaculture. Aquaculture 528: 735563. DOI: 10.1016/j.aquaculture.2020.735563.

Sanvicente-Añorve L, Zavala-Hidalgo J, Allende-Arandía E, Hermososalazar M. 2018. Larval dispersal in three coral reef decapod species: influence of larval duration on the metapopulation structure. PLoS ONE 13 (3): e0193457. DOI: 10.1371/journal.pone.0193457.

Setyanto A, Soemarno, Wiadnya DGR, Nugroho C. 2019. Biodiversity of Lobster (Panulirus) from Eastern Indian Ocean of Indonesia Waters. IOP Conf Ser Mater Sci Eng 546: 022024. DOI: 10.1088/1757899X/546/2/022024.

Sprintall J, Wijffels S, Molcard R, Jaya I. 2010. Direct evidence of the South Java Current system in Ombai Strait. Dyn. Atmos. Oceans 50: 140-156. DOI: 10.1016/j.dynatmoce.2010.02.006.

Swofford D. 1998. PAUP*. Phylogenetic Analysis Using Parsimony (*and Other Methods). Version 4. Sinauer Associates, Sunderland, Massachusetts.

Thompson JD, Gibson TJ, Plewniak F, Jeanmougi F, Higgins DG. 1997. The Clustal X-Window interface: Flexible strategies for multiple alignment through sequence alignment aided by quality analysis tools. Nucleic Acids Res 25: 4876-4882.

Utari PA, Setiabudidaya D, Khakim MYN, Iskandar I. 2019. Dynamics of the South Java Coastal Current revealed by RAMA observing 
network. Terr Atmos Ocean Sci 30: 1-11. DOI: 10.3319/ TAO.2018.12.14.01

Vaitheeswaran T. 2018. On rare occurrence of pronghorn spiny lobster, Panulirus penicillatus (Olivier, 1791) off Tuticorin coast, India $\left(08^{\circ} 35.912^{\prime} \mathrm{N}\right.$ and $\left.78^{\circ} 25.327^{\prime} \mathrm{E}\right)$ (25 M). J Agric Sci Bot 2 (1) 1-2. DOI: $10.35841 / 2591-7897.2 .1 .1-2$

Wahyudin RA. 2018. Dinamika Populasi dan Hubungan Keragaman Genetik Sumber Daya Spiny Lobster (Panulirus spp). [Disertasi]. Sekolah Pasca Sarjana, Institut Pertanian Bogor, Bogor. [Indonesian]
White C, Selkoe KA, Watson J, Siegel DA, Zacherl DC, Toonen RJ. 2010. Ocean currents help explain population genetic structure. Proc R Soc B Biol Sci 277: 1685-1694.

Wirasatriya A, Setiawan JD, Sugianto DN, Rosyadi IA, Haryadi H, Winarso G, Setiawan RY, Susanto RD. 2020. Ekman dynamics variability along the southern coast of Java revealed by satellite data. $\begin{array}{llll}\text { Intl J Remote Sensing } 41 & \text { (21): 8475-8496. DOI: }\end{array}$ 10.1080/01431161.2020.1797215. 